\title{
ACID AND ALKALINE PHOSPHATASES IN THEIR RELATION TO MALIGNANT DISEASE
}

\author{
By E. J. KING, M.A., PH.D., D.Sc. \\ Prefessor of Chsm.cal Pathology, Post Graduate Medical School, London \\ and \\ G. E. Delory, M.Sc., Ph.D. \\ Biochemist R yyal Infirmary, Preston, Lancashire
}

Phosphatases are enzymes capable of catalysing the hydrolysis of phosphoric esters with liberation of inorganic phosphate, they are found widely spread throughout nature. The early work on the discovery and properties of these enzymes has been thoroughly reviewed by Kay (1932).

\section{Acid and Alkaline Phosphatases}

There are probably many different phosphatases present in living organisms and much valuable data is being accumulated on their identity and methods of differential estimation. In the present state of our knowledge, however, and from the aspect of clinical application, we can best think of them in terms of two groups, the socalled ' alkaline' and ' acid' phosphatases. These enzymes are distinguished by the fact that the first class are optimally active at an alkaline and the second at an acid $\mathrm{pH}$. The actual $\mathrm{pH}$ varies with the particular substrate, but when phenyl phosphate is used, the acid phosphatases have an optimum $\mathrm{pH}$ of 4.9 and the alkaline phosphatases are optimally active at $\mathrm{pH} 9.8$. Since these $\mathrm{pH}$ values are sufficiently far apart, it is possible to determine one of the two groups of phosphatase in the presence of the other. It will be convenient in the first place to consider the two groups of phosphatases separately.

\section{Alkaline Phosphatases}

The foundation of our knowledge of the biological functions of the alkaline phosphatases was laid by Robison (1923) when he found an enzyme present in the ossifying cartilage of young rats and rabbits which liberated inorganic phosphate from hexose phosphate. This enzyme was optimally active at a $\mathrm{pH}$ 9.0-9.5 under the conditions used by him.

Robison suggested that alkaline phosphatase played a vital part in ossification, since enzymic hydrolysis of the phosphoric esters present in the fluids bathing the bone or cartilage led to a local increase in the concentration of inorganic phosphate in solution and thus to deposition of bone salt.

Following up this observation, Robison, Macleod and Rosenheim (I930) stated that their results 'set in sharp distinction two mechanisms in calcifying hypertrophic cartilage, (I) the phosphatase mechanism which produces in the matrix fluid a condition of supersaturation with respect to bone salts, and (2) the inorganic mechanism which favours deposition of this salt from super saturation.'

In the meantime, Martland, Hansman and Robison (1924) had demonstrated the presence of alkaline phosphatase in blood plasma, and Kay (1929) found raised levels in patients suffering from osteitis deformans (Paget's disease) and osteitis fibrosa cystica (Von Recklinghausen's disease). Kay suggested that raised plasma phosphatase levels might be due to leakage from the bones, where the enzyme had been produced in excess to compensate for the bone lesion, or might result from the bending of the weakened bones which squeezed out some of the cellular contents. Increased plasma alkaline phosphatase levels were also found in rickets (Demuth, 1925), cancer metastases in the bones (Coryn, r934) and in jaundice (Roberts, 1930). Later workers have confirmed and extended these findings, and the clinical value and limitations of plasma alkaline phosphatase estimations are now fairly well established. Critical reviews of this subject dealing fully with work up to the respective dates of publication have been presented by Morris and Peden (1937), by Franseen, Simmons and Maclean (1939) and by Sunderman (1942). These papers should be consulted for a more comprehensive list of references.

The plasma alkaline phosphatase is increased in a very large number of bone diseases, and attention has been concentrated on the elucidation of the common factors leading to this increase. 
Kay's hypothesis to account for enhanced plasma phosphatase values in bone disease has been extended by Bodansky and Jaffe (1934). They suggest that the level of alkaline phosphatase in the plasma is a reflection of bone cell activity, and that one of the factors controlling this activity may be developed in the process of normal bone formation. Thus, in active rickets, normal bone formation does not take place, the normal inhibitory factor will not appear or will only appear in inadequate amount, and the increased cellular activity will be paralleled by an increased plasma phosphatase level. On treatment, normal bone begins to form, the normal controls come into play, the cellular activity is controlled at progressively lower levels and the plasma alkaline phosphatase level falls. The nature of these controlling factors and their mode of operation is still obscure.

Franseen, et al. (1939) have classified the groups of bone lesions in which raised alkaline phosphatase values are found as follows : (I) abnormal or neoplastic proliferation of bone ; (2) frustrated attempts at osteogenesis with the production of osteoid tissue ; and (3) reparative processes accompanying or following inflammatory, traumatic or neoplastic destruction of the architecture or continuity of bone.

Thus raised plasma alkaline phosphatase levels, so far as bone disease is concerned, are invariably associated with osteoblastic activity. In cancer with metastases in the bones, $\mathrm{X}$-ray examination may show the lesion to be purely destructive, nevertheless histological examination invariably shows some attempt at repair. The plasma alkaline phosphatase level will, therefore, depend on the nature and extent of the lesion. Where there is a single lesion of the type mentioned the plasma enzyme content may not be raised, but with many lesions an enhanced value is always found. Where osteoplastic lesions occur, extremely high values have been recorded; while in conditions such as myelomatosis where the lesion is purely destructive as seen by histological examination, the plasma alkaline phosphatase is normal or at most only slightly raised.

Although we are not concerned here with jaundice, it should be mentioned in passing that the high blood alkaline phosphatase values found in this condition are probably due to absorption into the blood stream of bile which is a rich source of this enzyme (Armstrong, King and Harris, 1934).

Further reference to alkaline phosphatase is made in a later section.

\section{Normal Values for Alkaline Phosphatase in Plasma}

Methods for the estimation of alkaline phos- phatase depend on the estimation of either (I) the 气 amount of inorganic phosphate liberated by the $\frac{3}{0}$ enzyme from sodium $\beta$-glycero phosphate (Jenner and Kay, 1932) (Bodansky, 1933) or (2) the amount of phenol liberated from phenyl phosphate (King and Armstrong, 1934). In each case, the hydrolysis is allowed to proceed at $37^{\circ}$ for a stated time at a stated $\mathrm{pH}$ and the results expressed in arbitrary units. As a consequence, the normal $\vec{\sigma}$ values will depend on the method employed. For three of the methods which have been most is commonly employed the normal values are given $\vec{\circ}$ as Bodansky: I-4, Jenner and Kay : 3-8 and King and Armstrong: 3-13. All values are expressed as units per $100 \mathrm{ml}$.

It is not easy to convert the value for one method to that for another by means of a factor, because of the differing behaviour of the enzyme + under the various conditions, and each published result has to be considered in terms of the normal finding for the method employed. As a rough yardstick, however, the King and Armstrong and the Jenner and Kay units are approximately equal and values obtained by these methods are about 2.5 times the corresponding Bodansky value.

\section{Acid Phosphatase}

Our awareness of the clinical importance $\frac{0}{9} \frac{+}{9}$ acid phosphatase determinations has been bui mainly on the valuable work of Kurtscher and he colleagues in Germany and the two American schools ; those of Gutman and of Huggins.

Studying the source of the enzyme which Demuth (1925) had found to be present in human urine, Kurtscher and Wolbergs (1935) showed the presence of large amounts of acid phosphatase in prostatic tissue and made a careful study of its properties.

In a series of publications from 1936 onwards, the Gutmans reported investigations which confirmed and extended Kurtscher's observations, and 3 . recorded important advances in our knowledge of $\delta$ prostatic phosphatase. The concentration of the enzyme in the human prostate gland is between $\mathrm{O}$ 500 and 2,500 units per gm. of wet tissue, and in the seminal fluid it is present in concentrations varying from 700 to 3,700 units per $\mathrm{ml}$. It is absent from or only present in very small amount before 0 puberty, but it can be produced precociously in N the immature Rhesus monkey by injection of N

testosterone propionate.
Gutman and Gutman (1938) noted that this phosphatase was also present at the site of bone metastases secondary to prostatic carcinoma and $\stackrel{\mathscr{D}}{\oplus}$ that the plasma enzyme level was raised, often markedly, in the serum of patients suffering from metastasizing prostatic carcinoma. This observa- $\overrightarrow{\mathbb{D}}$ tion has proved to be one of the most fruitful of $\frac{\Omega}{\mathbb{D}}$ 
our time, and a considerable number of publications have testified to its clinical importance.

Gomori (1939, 194I) has developed histological techniques for the demonstration of the phosphatases, and has shown that acid phosphatase occurs in the cells of the prostatic epithelium where it is apparently produced.

Using Gomori's technique, and also following plasma acid and alkaline phosphatase levels in prostatic cancer, Huggins, Stevens and Hodges (I94I) concluded that "prostatic carcinoma is often composed of epithelial cells of a mature type, which in common with all other types of adult prostatic epithelium is responsive to depression of the levels of androgenic hormones in the organism.'

The significance of these observations will be discussed in a subsequent section.

\section{Normal Values for Acid Phosphatase}

Most of the acid phosphatase determinations given in the literature have been determined by methods which are modifications of the King and Armstrong procedure, in which a buffer solution of $\mathrm{pH}_{5}$ is used, instead of that of $\mathrm{pH}$ ro used in the alkaline phosphatase procedure. Unfortunately, however, all workers have not used the same hydrolysis time. The acid phosphatase level of normal plasma is so low, and consequently the amount of phenol liberated is so small, that the Gutmans have used hydrolysis periods of three to five hours and calculated the enzyme value by dividing by the number of hours hydrolysis.

Such long periods of hydrolysis are, however, very inconvenient, especially in routine work, and consequently some workers have made use of shorter incubation times, for example, one hour. Since, however, there is not a straight line relationship between the time of hydrolysis and the amount of phenol liberated, the values for a one hour period will be greater than those obtained when a longer time is used and the one hour figure obtained by calculation. Huggins and Hodges (194I) have used a 30 minute period of hydrolysis. .In passing it may be mentioned that the objection to the one hour method, namely the difficulty of measuring the small amount of phenol liberated, may be met to some extent by using a good photoelectric colorimeter (or a Pulfrich photometer), and taking precautions to keep the blank contributed by the reagents down to a minimum.

The normal values thus depend on the standard time adopted, and are given as follows :-

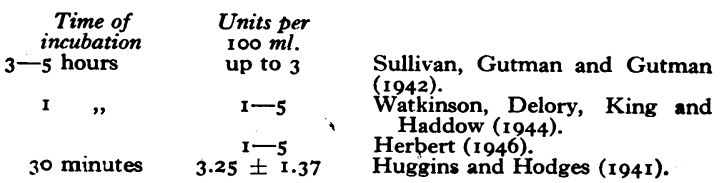

Effect of Castration and the Administration of Androgens and Oestrogens on the Phosphatases in Prostatic Carcinoma

Huggins and Hodges (194I) studied the effect of castration and the administration of androgens and oestrogens on the plasma phosphatases in patients with metastatic carcinoma of the prostate. They chose patients who showed a markedly raised serum acid phosphatase, and found that the acid phosphatase level fell rapidly after bilateral orchidectomy, usually reaching or approaching normal values within 12 days. The alkaline phosphatase on the other hand rose at first but later fell. Similar results were found after administration of stilboestrol. The fall in the acid phosphatase level was usually accompanied by clinical improvement. This aspect has been reviewed by Haddow (1943).

After administration of testosterone propionate, however, the serum acid phosphatase level rose. When the injections were stopped there was a fall to the pre-injection level. No changes were detected in the alkaline phosphatase concentration during treatment, but on cessation of the administration it tended to rise.

The effect of castration was confirmed by Sullivan, Gutman and Gutman (1942) who made a careful study of 33 patients, 31 of whom hado pre-operative serum acid phosphatase levels ranging from 4.2 to 520 units per $100 \mathrm{ml}$. In every case except one (one of two patients who had been: castrated by a different technique in which the tunica was left in situ after removal of the contents) an immediate fall in acid phosphatase took place which was usually demonstrable within 24 hours. The serum acid phosphatase continued to fall, the decline being on the average 55 per cent. of the pre-operative level on the second, and 64 per cent. on the fourth post-operative day. One week after castration the mean fall was 70 per cent. of the original value and after two weeks 73 per cent. At about the third week there was a slight transitory rise, but after this time, the decline continued until at the end of 2-3 months it reached an equilibrium value, which was usually 5 units or less when the original level was not greater than 30 units per $100 \mathrm{ml}$. Where the original level was very high, however, the equilibrium value was often still markedly raised.

The effect of castration on the serum alkaline phosphatase was found by these workers to be more variable. During the first few days following castration, there was either no significant change, or erratic fluctuations below or above the initial value. About the second or third week, the alkaline phosphatase concentration usually rose, sometimes to more than twice the pre-operative level. Thereafter, the level fell slowly until 
after many months it reached a steady level, which was usually nearer normal than the pre-operative value.

As Huggins and Hodges (194I) point out, these findings are in keeping with the idea that the two groups of phosphatase are the result of the activity of two different types of cells, prostatic epithelium and osteoblasts, the former being controlled, at least in part, by the action of the androgens present in the body. Following castration, androgen production falls, and consequently the serum acid phosphatase level decreases rapidly. The raised serum alkaline phosphatase levels, on the other hand, are due to increased osteoblastic activity of the bone and show no consistent early response to castration. After a latent period, however, further increased osteoblastic activity begins to occur, and the alkaline phosphatase increases still further. This, as Sullivan, et al. (1942) point out, is associated with increased osteoblastic healing of skeletal metastases, often seen as increased density of X-ray films 2-3 months after operation. As the extra bone formation lessens, the serum alkaline phosphatase level falls. These findings have been confirmed in all essentials by many workers, e.g., Kahle, Ogden and Getzoff (1942) and Watkinson, Delory, King and Haddow (1944). The latter workers also reported one case treated with triphenylchlorethylene in which the serum acid phosphatase level rose from 20 units per $100 \mathrm{ml}$. to between 40 and 50 at 5 months, after which it dropped to reach a normal level at about 8 months after the beginning of treatment.

\section{Separate Estimation of Enzymes in the Acid Phosphatase Group}

As indicated in the introduction to this article, there are probably several enzymes in the blood which are estimated by the ordinary acid phosphatase procedures.

Our knowledge of the identity of the various enzymes is increasing rapidly at the present time, and the following account must therefore be regarded as subject to considerable change in the next few years.

It is evident that there are at least two acid phosphatases in the blood other than that coming from the prostate gland. One of these is to be found in the red cells, and it is for this reason that haemolysed blood should not be used for prostatic acid phosphatase estimations by the ordinary procedures. Another non-prostatic enzyme occurs normally in the serum, not only of men, but also of women.

Methods have, therefore, been devised which attempt to estimate the prostatic enzyme separately in the presence of the other acid phosphatases. Such methods depend on the use of substances which will inactivate one or other 0 the enzymes.

Herbert (1946) has employed incubation with 40 per cent. alcohol at room temperature for $30 \stackrel{c}{C}$ minutes to inactivate the prostatic component and this to determine it indirectly. Thus, prostatic $\stackrel{5}{+}$ phosphatase is represented by the difference be- $\bar{C}$ tween the values for the untreated and the alcohol- 흠 treated samples. Herbert has also studied a $\frac{\overline{\bar{\sigma}}}{\bar{\sigma}}$ method which depended on inactivation of $\stackrel{\Phi}{\complement}$ prostatic phosphatase by incubation of the serum \& alone at $37^{\circ}$. This second method, however, $\stackrel{\infty}{\circ}$ proved not to be entirely specific.

Another approach to this question of the estimation of prostatic, in the presence of other, $\stackrel{\sigma}{\sigma}$ acid phosphatases has been made possible by the $\overrightarrow{0}$ observation of Abul-Fadl and King (1947) that 3 0.5 per cent. formaldehyde completely inactivates in red cell acid phosphatase and destroys most of the normal serum enzyme, but has no effect on the N prostatic enzyme.

\section{Serum Phosphatase Levels in Disease}

Table I, adapted from Sunderman, indicates the level of acid and alkaline phosphatase to be expected in disease. As already mentioned, a $\overparen{D}$ raised alkaline serum phosphatase value in bone $\vec{\oplus}$ conditions is invariably associated with increaseg $\stackrel{\oplus}{\infty}$ osteoblastic activity, rather than a specific bone. disease, whereas an increase in the serum act? phosphatase is usually associated with metastasizing carcinoma of the prostate. It is not sur- oे prising, therefore, that all workers have failed to detect any correlation between the concentration of the two enzymes in the serum in this condition, $\overrightarrow{\overrightarrow{0}}$ for, although both the acid and the alkaline 3 phosphatase levels may be raised, each of the enzymes is elaborated by a different type of cell.

It is not so easy, however, to see why, in conditions such as Paget's disease, where a marked increase in alkaline phosphatase occurs, there may also be an increase in acid phosphatase. The first hypothesis to be investigated was that the alkaline enzyme was not completely inactivated at $\mathrm{pH}_{4.9}$, and that consequently some hydrolysis could take 윽 place at this $\mathrm{pH}$. Such hydrolysis, although due to $D$ the activity of the alkaline enzyme, would, of course, be recorded as due to a different enzyme, $N$ namely acid phosphatase. This was found by Gutman, Gutman and Robinson (1940) not to be $\stackrel{N}{\circ}$ the case, a view with which all subsequent in- N vestigators agree. Abul-Fadl and King (1947) have suggested that the bones of actual cases of 0 Paget's disease may contain an acid phosphatase $\mathbb{D}$ not present in normal bone, although they did not $\stackrel{?}{?}$

have an opportunity of testing this point.
Although all workers have confirmed the Gutmans' important observation that the serum acid 
TABLE I

Sfrum Acid and Alkalinei Phosphatase in Disease. Adapted from Sunderman (1942).

\begin{tabular}{|c|c|c|}
\hline & PhOS & HATASE \\
\hline Disease & ALKALINE & ACID \\
\hline $\begin{array}{l}\text { Prostatic cancer : } \\
\text { (a) with bone meta- } \\
\text { stases. } \\
\text { (b) without bone } \\
\text { metastases. } \\
\text { Other diseases of pros- } \\
\text { state. } \\
\text { Osteitis deformans. } \\
\text { Osteitis fibrosa cystica. } \\
\text { Osteogenic sarcoma. } \\
\text { Myelomatosis. } \\
\text { Other bone tumours. } \\
\text { Canc er of organs } \\
\text { (other than prostate) } \\
\text { with bonemetastases. } \\
\text { Rickets. } \\
\text { Osteomalacia. } \\
\text { Senile osteoporosis. } \\
\text { Osteogenesis imper- } \\
\text { fecta. } \\
\text { Jaundice. }\end{array}$ & $\begin{array}{l}\text { Normal or } \\
\text { slightly raised. } \\
\text { Normal. } \\
\text { Normal. } \\
\text { Markedly raised. } \\
\text { Markedly raised. } \\
\text { Raised. } \\
\text { Normal. } \\
\text { Normal or raised. } \\
\text { Normal or raised. } \\
\text { Raised. } \\
\text { Raised. } \\
\text { Normal. } \\
\text { Normal or raised. } \\
\text { Markedly raised } \\
\text { in obstructive, } \\
\text { less so in toxic, } \\
\text { and normal in } \\
\text { haemolyt ic } \\
\text { jaundice. }\end{array}$ & $\begin{array}{l}\text { Usually markedly } \\
\text { raised. } \\
\text { Most frequently nor- } \\
\text { mal. } \\
\text { Normal. } \\
\text { Normal or slightly } \\
\text { raised. or slightly } \\
\text { Normal or } \\
\text { raised. } \\
\text { Usually normal. } \\
\text { Normal. } \\
\text { Usually normal. } \\
\text { Usually normal. } \\
\quad \text { - } \\
\text { - } \\
\text { May be slightly raised. }\end{array}$ \\
\hline
\end{tabular}

phosphatase is most frequently raised in metastatic prostatic carcinoma, there seem to be occasional apparent exceptions. For this reason, and because much of the work has been carried out quite recently, the question of serum acid phosphatase levels in disease will be reviewed in some detail.

Table 2 shows the number of cases of prostatic cancer, with and without bone metastases, in which various workers have reported raised serum acid phosphatase values. The particular authors' own normal value has been adopted in deciding whether a given value is raised or not. This table also includes, for convenience, results of analyses in which attempts were made to distinguish the prostatic from the other acid phosphatases by means of alcohol and formalin. These observations will be discussed later on.

All workers agree that the serum acid phosphatase level is raised in most, but not all, cases of prostatic cancer, and that such rises are more likely to be found when bone metastases are demonstrable. The higher the value, the more likely are bone metastases to be present. To illustrate this point, among Sullivan's, et al. I30 cases with bone metastases, 25 per cent. gave results between 5 (upper limit of normal 3 ) and 9.9 units per $100 \mathrm{ml}$., 48 per cent. gave higher figures still, while 4 per cent. gave values more than 1,000 units per $100 \mathrm{ml}$. On the other hand, among their cases without bone metastases, the concentration was never greater than 4.9 units per $100 \mathrm{ml}$.

In Table 3 , the findings of three groups of
workers-Sullivan, et al., Herbert, and AbulFadl and King have been collated to illustrate the frequency with which they obtained high values in disease other than prostatic cancer. All the $\stackrel{C}{c}$ workers do not classify their results in exactly the same way. For example, Herbert has included $2 \mathrm{r} \stackrel{\vec{S}}{\rightarrow}$ cases of cancer of organs (other than the prostate)음 without bone metastases in the general miscellaneous group. Similarly, the miscellaneous group $\frac{\bar{c}}{\frac{\bar{c}}{\sigma}}$ of Sullivan, et al., described as including ' $\mathrm{a} \stackrel{\mathbb{\complement}}{\propto}$ variety of infections, degenerative diseases, metabolic disorders, blood dyscrasias, etc.,' may well ${ }^{\text {s }}$ include kidney conditions classified separately by $\vec{\circ}$ the other workers. Nevertheless, the Table gives $\overrightarrow{-}$ a fair picture of the distribution of enhanced $\stackrel{\omega}{\sigma}$ serum acid phosphatase values.

It is interesting to note that in the three cases in the general miscellaneous group of Sullivan, et al., i giving raised values, one (a case of Hodgkin's $\dot{\text { in }}$ disease involving the liver and probably bones) $N$ showed a result of 4.2 units per $100 \mathrm{ml}$. The i second, of uncertain diagnosis, gave a figure of $\bullet$ 3.2 units per $100 \mathrm{ml}$., while the third was a patient $\mathrm{O}$ with sickle-cell anaemia in haemolytic crisis. In this patient, the serum acid phosphatase levels $c_{\subseteq}$ rose from 2.7 to 6.9 and then to 14.6 units per $100 \mathrm{ml}$ as the red cell count fell. The high figures here were attributed to liberation of re cell phosphatase as a result of haemolysis in vive.

Among the cases of prostatic cancer withou demonstrable metastases, no results greater than 4.9 units per $100 \mathrm{ml}$. were recorded.

'Two of Herbert's cases of benign prostatic hyperplasia gave abnormal figures for serum acid $\stackrel{\varnothing}{\varnothing}$ phosphatase. In one of them, the increase was $\overrightarrow{\vec{P}}$ very slight- 5.4 (upper limit of normal 5.0 ) units $\frac{3}{3}$ per $100 \mathrm{ml}$, while in the other case, three estimations, made within four days, gave the following results : first day-3.5, second day-8.8, and fourth day -5.2 units per $100 \mathrm{ml}$.

Employing the alcohol technique to which reference has already been made, Herbert found that the addition of alcohol to sera in the non- 8 prostatic diseases usually led to no significant $₹$ change in the serum acid phosphatase concentra- 0 tion, although sometimes it caused a definite rise, and sometimes a slight fall. From 102 cases of non-prostatic disease, there were only two exceptions to the rule that alcohol treatment does 0 not cause a fall of more than one unit in the enzyme $N$ level. All the 14 cases of non-prostatic disease $\underset{\omega}{N}$ found to have total serum acid phosphatase concentrations greater than 5 units per $100 \mathrm{ml}$. conformed to this rule. In five of the cases of prostatic cancer in which bone metastases were not demonstrated, or where there was no radiological ex- 0 amination, a significant fall occurred after alcohol 0 treatment, despite the fact that the total acid $\stackrel{\mathbb{Q}}{\circ}$ 
TABLE 2

Serum Acid Phosphatase in Prostatic Carcinoma.

Adapted and extended from Herbert, 1946.

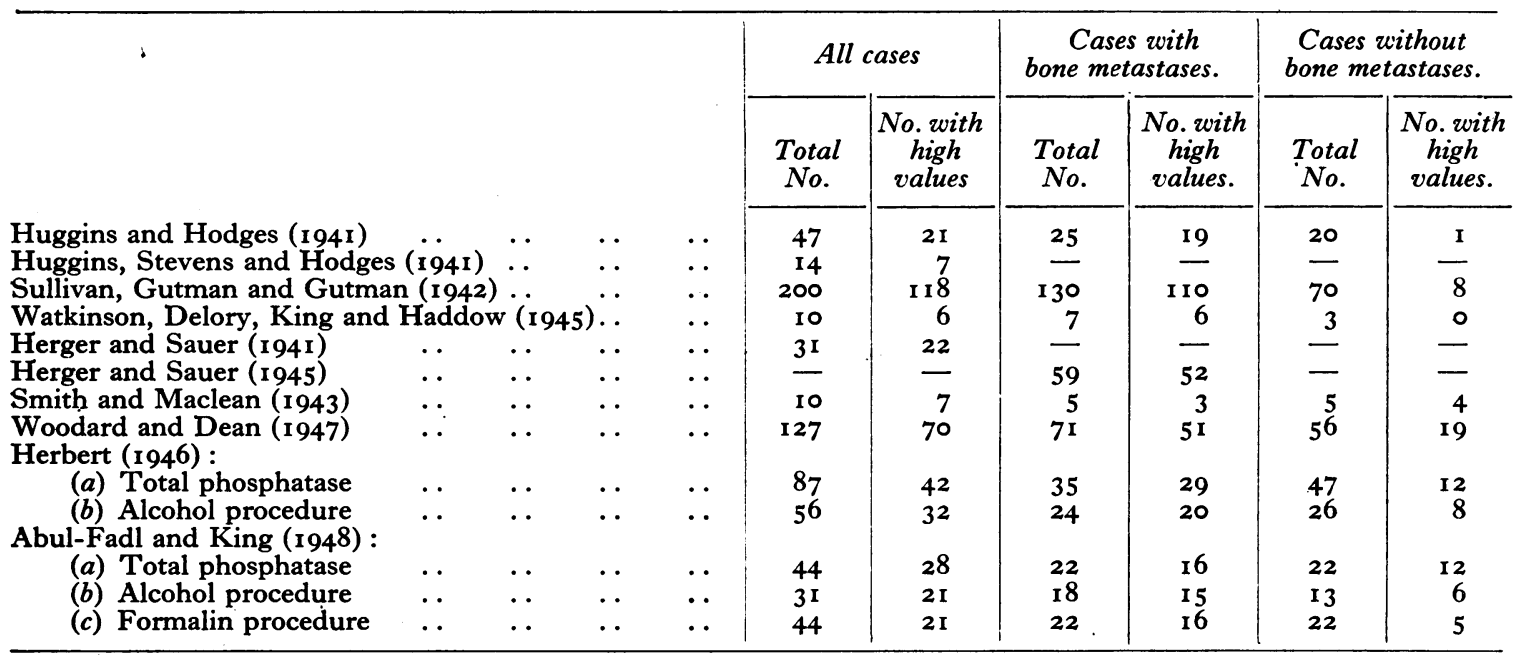

phosphatase was within normal limits. On the other hand, in every case where the presence of metastases was established, and the serum acid phosphatase content was originally raised, it fell on treatment with alcohol, usually, although not always, to the normal level.

The findings of Abul-Fadl and King agree, in general, with those of the other workers, although they find a greater proportion of raised values in conditions other than metastasizing prostatic cancer. Some of their figures for these conditions show very significant increases over the normal (5 units per $100 \mathrm{ml}$.), the two highest figures in the general miscellaneous group being 25 (in a case of myeloid leukaemia) and 24 units per $100 \mathrm{ml}$. (in a case of bronchopneumonia).

These workers found that their formalin procedure, despite occasional failures, was of clinical help in distinguishing between prostatic cancer and other diseases. In the high figure for bronchopneumonia quoted above, for example, the value after treatment with formalin was only 1.8 units per $100 \mathrm{ml}$., thus indicating that the high serum phosphatase value found originally was due to acid phosphatases other than that from the prostate. In the figures given in Table 2 and Table 3 for the formalin procedure, the upper limit of normal is taken as 4 units per $100 \mathrm{ml}$. Only seven out of 57 cases in Abul-Fadl and King's general miscellaneous group gave results greater than 3 units per $100 \mathrm{ml}$. after treatment with formalin; the highest figure (6.6 units per $100 \mathrm{ml}$.) being found in a case of steatorrhoea with total acid phosphatase 12 units and associated raised serum alkaline phosphatase (48 KingArmstrong units per $100 \mathrm{ml}$.). Of the seven raised serum formalin resistant acid phosphatase values, only five were greater than 4.0 units per $100 \mathrm{ml}$.

In the 22 cases of prostatic cancer with demonstrable metastases $\mathrm{I} 6$ (that is all the cases with original high total acid phosphatase) showed serum formalin resistant enzyme greater than 4 units per $100 \mathrm{ml}$.

The value of formalin, in distinguishing raised serum acid phosphatase due to the prostatic enzyme from those where the enzyme originates elsewhere, has been confirmed independently by one of us (G.E.D.) in a series not yet sufficiently comprehensive for publication.

Abul-Fadl and King also tried Herbert's alcohol procedure in a large number of their cases. Their findings showed that falls in serum acid phosphatase concentration after alcohol treatment occurred more frequently, and to a greater degree in prostatic cancer than in other conditions. The fall in these other conditions was, however, very often much greater than $\mathrm{r} .0$ units per $100 \mathrm{ml}$. (the figure given by Herbert) and occasionally greater than 2.0 units per $100 \mathrm{ml}$.

In the 15 cases of untreated prostatic cancer with bone metastases studied by the alcohol technique, and where the serum total acid phosphatase level was raised, the fall on alcohol treatment was greater than 7 units per $100 \mathrm{ml}$. in 14 cases, while in the other case it was 1.4 units per roo $\mathrm{ml}$. Among the cases of this condition, when the serum acid phosphatase was not originally raised, the fall was 3.8 and $\mathrm{I}$.I respectively in two 
TABLE 3

Serum Acid Phosphatase in Diseases other than Prostatic Cancer.

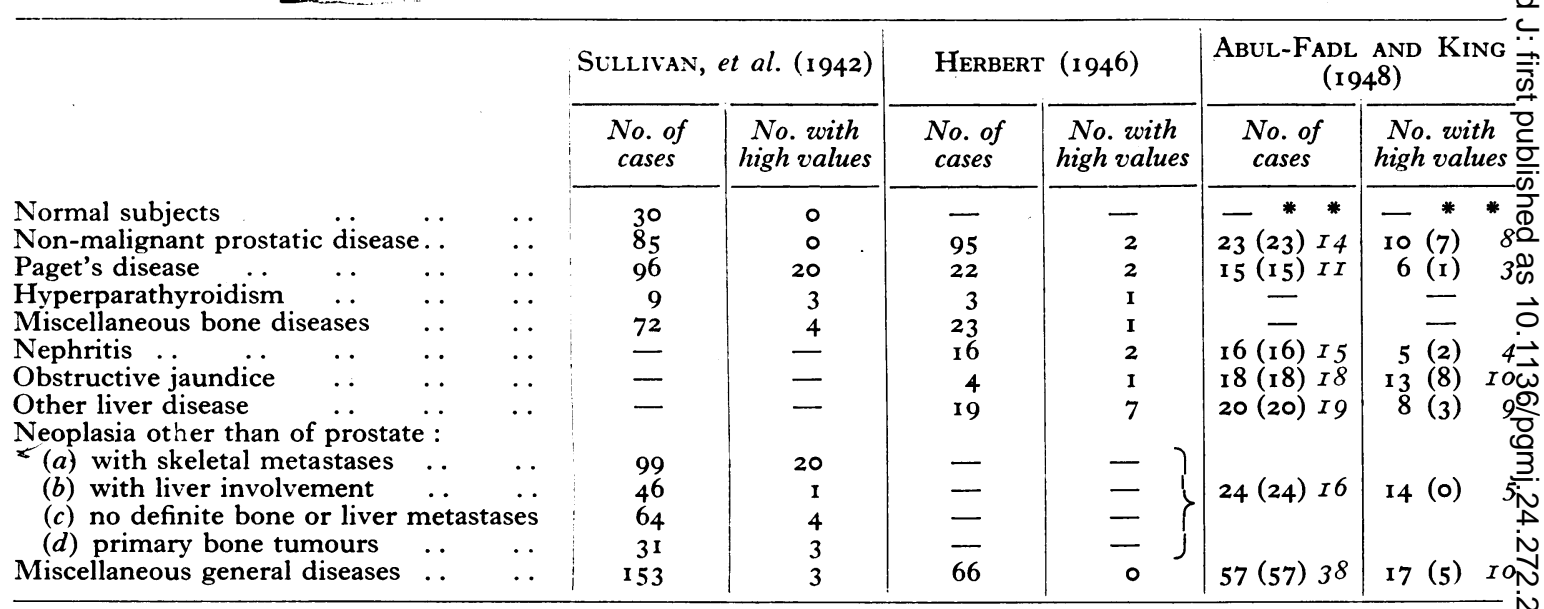

*Figures in brackets show the number of cases investigated by the formalin method and the number giving values@ greater than 4 units per $100 \mathrm{ml}$.

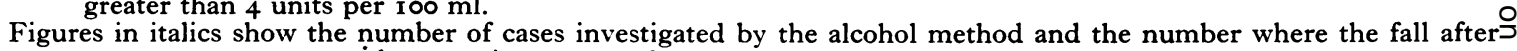
treatment was greater than $\mathrm{I}$ unit per $100 \mathrm{ml}$.

of the six cases studied, and less than 1.0 in the others.

\section{Clinical Value of Phosphatase Determina- tions}

\section{(a) Alkaline phosphatase}

So far as the value of serum alkaline phosphatase estimations in the differential diagnosis of neoplasia is concerned, little can be added to reviews already published (e.g., Morris and Peden, I937, and Sunderman, 1942). The following is a brief summary of the position. In malignant disease, where there is no involvement of bone or liver, the serum alkaline phosphatase is normal, but where bone metastases are present, raised values are usually recorded. Such raised values are associated with increased osteoblastic activity and are, therefore, found in so many bone conditions that, by itself, alkaline phosphatase estimation is of little value in differential diagnosis, although it may be of help when considered in relation to clinical, radiological and other biochemical findings. It is claimed that it may be of value in the diagnosis of multiple myelomata in the early stages, since the serum alkaline phosphatase is normal, or only slightly raised in this condition in contra-distinction to Paget's and Von Recklinghausen's disease where very high values are often found.

\section{(b) Acid phosphatase}

In assessing the value of acid phosphatase estimations in prostatic cancer, two things must be established. Firstly, the constancy with which raised values are encountered in prostatic cancer, $\overrightarrow{0}$ and secondly, the frequency with which suogho values are found in other conditions. These two questions will be considered separately. It Is: generally agreed that raised serum acid phosphatase values are found in most, but not all, casesn of carcinoma of the prostate with bone metastases. As Sullivan, et al. point out, excluding the possibility of errors in diagnosis or in the chemicala estimation, there are three other possible causes of failure which have to be considered, (I) the extent of the invasion of blood and lymph channels in a particular case may not be sufficiently great to? allow large amounts of the prostatic enzyme to pass into the blood stream, (2) the neoplastic prostate tissue, in some patients, may producei small quantities of acid phosphatase and (3) the serum enzyme level may have been lowered by
treatment.

Sullivan found that some (but not all) of theo cases in which normal serum acid phosphatase values were found were in patients with markedlyos anaplastic tumours, and in one case, the tumoun itself was found to show very little enzyme activity Herbert also found the tumour to be anaplastic ${ }^{\omega}$ in one of her cases with bone metastases, in which a normal serum acid phosphatase value was obtained.

So far as the serum acid phosphatase concentra: tion in diseases other than prostatic cancer with metastases is concerned, the work of Abul-Fadp and King suggests that marked increases may be्षे 
found more frequently than has been thought hitherto. Such increases are, however, often due to an acid phosphatase which may be distinguished from prostatic phosphatase by the use of substances which inactivate the various enzymes in a different degree. The stimulus which the introduction of alcohol and formalin has given will, undoubtedly, lead to further advances in our knowledge of this subject. Apart from inactivation experiments, clinical findings may also be of value in deciding whether an increased serum acid phosphatase concentration is from a non-prostatic source.

All workers are agreed with the statements of Sullivan, et al. on the place of serum acid phosphatase estimations in the diagnosis of metastasizing prostatic cancer. The main value is in those patients suspected on clinical grounds, and from $\mathrm{X}$-ray evidence, of metastasizing prostatic cancer, and where confirmation is sought. When the $\mathrm{X}$-ray findings are inconclusive, the diagnosis may be established by the phosphatase estimation, and it is often possible to anticipate the X-ray demonstration of bone metastases by several months. Conversely, where the presence of metastases is definitely established, evidence may be obtained for or against the possibility that the primary tumour is in the prostate where this is in doubt. The estimation is also helpful in following the course of therapy.

\section{(c) Acid and alkaline phosphatase}

Table I, already mentioned, indicates the typical findings for serum acid and alkaline phosphatase in various conditions.

The simultaneous estimation has proved of especial value in distinguishing prostatic cancer with osteoplastic bone metastases from localized Paget's disease. In Paget's disease the serum alkaline phosphatase is markedly increased while the acid phosphatase is normal or only slightly increased, except when there is such extensive involvement that both phosphatases become further increased, in which case Paget's disease is easily recognized by its very high alkàline phosphatase values.

\section{BIBLIOGRAPHY}

ABUL-FADL, M. A. M., and KING, E. J. (1947), Biochem. f., ABU LI, xxxii. Path., I, 80.

ARMSTRONG, A. R., KING, E. J., and HARRIS, R. J. (1934), Canad. Med. Ass. ̈., $\mathbf{3 1}, 14$.

BODANSKY, A. (1933), F. Biol. Chem., ror, 93

BODANSKY', A., and JAFFE, H. L. (1934), Arch. Int. Med., 54, 88. CORYN, G. (1934), $¥$. de Chir. et Ann. de la Soc. Belge de Chir., $33,168$.

DEMUUTH, F. (1925), Biochem. Z., 159, 415.

FRANSEEN, C. G., SIMMONDS, C. G., and MACLEAN, R. (1939), Surg. Gyn. Obst., 68, 1038.

GOMORI, G. (1939), Proc. Soc. Exp. Biol. Med., 42, 23.

GOMORI, G. (194I), Arch. Path., 32, 189.

GUTMAN, A. B., and GUTMAN, E. B. (1038), f. Clin., 17, 273. TMAN, A. B., GUTMAN, E. B., and ROBINSON, J. N. (1940), Am. F. Cancer, 38, 103.

HADDOW, A. (1943), Brit. F. Radiol., 16, 193

HERBERT, F. K. (1946), Quart. F. Med., 59,221

HERGER, C. C., and SAUER, H. R. (1941), F. Urol., 46, 286.

HERGER, C. C., and SAUER, H. R. (1945), Surg. Gyn. Obst.,

$80,128$.

HUGGINS, C., and HODGES, C. 'V. (I941), Cancer Res., I, 293. HUGGINS, C., STEVENS, R. E., and HODGES, C. V. (1941), Arch. Surg., 43, 409.

JENNER, H. D., and KAY, H. D. (1932), Brit. F. Exp. Path., 13, 22.

KAHLE, P. J., OGDEN, H. D., and GETZOFF, P. L. (1942), ₹. Urol., 48, 83 .

KAY, H. D.' (1929), Brit. F. Exp. Path., ro, 253.

KAY, H. D. (1932), Physiol. Rev., 12, 384. KURT'SCHER, W., and WOLBERGS, H. (1935), Z. Physiolẹ Chem., 236, 237. HAUSMAN, F. S., AND ROBISON, R.

(1924), Biochem. F., 18, 1152 . ROBERTS, W. M. (1930), Brit. Med. Э., 1, 734.

ROBISON, R. (1923), Biochem. F., 17, 286.

ROBISON, R., MACLEOD, M., and ROSENHEIM, A. H. (1930), Biochem. $\mathcal{F} ., 24,1927$.

SMITH, E., and MÄ̌LEAN, J. T. (1943), Canad. Med. Ass. F., SULL, 387.

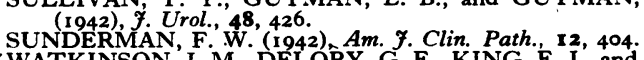

i WATKINSON. J. M., DELORY, G. E., KING, E. J., and HAD. DOW, A. (1944), Brit. Med. Y., 2, 492.

WOODARD, H. Q., and DEAN, A.' L. (1947), f. Urol., 57, 158.

\section{RUTHIN CASTLE, NORTH WALES}

A Clinic for the diagnosis and treatment of Internal Diseases (except Mental or Infectious Diseases). The Clinic is provided with a staff of doctors, technicians and nurses.

The surroundings are beautiful. The climate is mild. There is central heating throughout. The annual rainfall is 30.5 inches, that is, less than the average for England.

The Fees are inclusive and vary according to the room occupied.

For particulars apply to THE SECRETARY, Ruthin Castle, North Wales.

Tolograms : Castle, Ruthin.

Telephone: Ruthin 66 